\title{
STUDI LITERATUR PENGARUH PEMBERIAN EKSTRAK DAUN BAYAM MERAH (AMARANTHUS TRICOLOR L.) TERHADAP KADAR SGOT DAN SGPT PADA TIKUS PUTIH JANTAN GALUR WISTAR YANG DIBERI DIET TINGGI LEMAK
}

\author{
${ }^{1}$ Hetti Rusmini, ${ }^{2}$ Dita Fitriani, ${ }^{3}$ Ade Maria Ulfa, ${ }^{4}$ Lu'lu' Rif'atunnissa \\ ${ }^{1}$ Departemen Farmakologi Fakultas Kedokteran Universitas Malahayati \\ ${ }^{2}$ Departemen Kimia Medik Fakultas Kedokteran Universitas Malahayati \\ ${ }^{3}$ Studi Farmasi Fakultas Kedokteran Universitas Malahayati \\ ${ }^{4}$ Program Studi Kedokteran Fakultas Kedokteran Universitas Malahayati \\ 1'hettirusmini@gmail.com, 2dita@malahayati.ac.id, ${ }^{3}$ rifatunnissalulu@gmail.com
}

\begin{abstract}
The prevalence of hyperlipidemia in Indonesia is increasing from year to year, in 2008 it was recorded at 35.1\%. Then in 2013 it increased to 35.9\%. Increased hyperlipidemia triggers NonAlcoholic Fatty Liver Disease (NAFLD). NAFLD conditions cause liver cell damage, thereby increasing levels of liver enzymes such as SGOT and SGPT. According to Pradana et al. (2017) stated that red spinach leaf extract has antioxidant activity that is able to inhibit the incision of the oxidation chain reaction because it contains flavonoid compounds, quercetin, tannin, and saponins which have the potential as a preventive therapy for fatty liver. To determine the effect of red spinach leaf extract (Amaranthus tricolor L.) on SGOT and SGPT levels in white rats (Rattus norvegicus) fed a high-fat diet. The research method uses a literature study. The database in the literature study was obtained from Google Scholar, PubMed and NCBI which was taken by Population, Intervention, Comparation, Output, Study, and Time (PICOST). From 5,166 journal articles obtained, 8 journal articles were found that discussed the effect of red spinach leaf extract (Amaranthus tricolor L.) on SGOT and SGPT levels given a high-fat diet. The dose is $200 \mathrm{mg} / \mathrm{kgBW}$ and $400 \mathrm{mg} / \mathrm{kgBW}$ with a duration of administration of 7 to 29 days.
\end{abstract}

Keyword : High Fat Diet, Hyperlipidemia, NAFLD, Red Spinach Extract, SGOT, SGPT, White Rat

\begin{abstract}
ABSTRAK
Prevalensi hiperlipidemia di Indonesia meningkat dari tahun ke tahun, pada tahun 2008 tercatat sebesar 35,1\%. Kemudian pada tahun 2013 meningkat menjadi 35,9\%. Peningkatan hiperlipidemia menjadi pemicu Non-Alcoholic Fatty Liver Desease (NAFLD). Kondisi NAFLD menyebabkan kerusakan sel hati sehingga meningkatkan kadar enzim hati seperti SGOT dan SGPT. Menurut Pradana et al. (2017) menyatakan bahwa ekstrak daun bayam merah memiliki aktivitas antioksidan yang mampu menghambat insisi dari reaksi rantai oksidasi karena mengandung senyawa flavonoid, kuersetin, tannin, dan saponin yang berpotensi sebagai terapi preventif perlemakan hati. Mengetahui pengaruh pemberian ekstrak daun bayam merah (Amaranthus tricolor L.) terhadap kadar SGOT dan SGPT pada tikus putih (Rattus norvegicus) yang diberi diet tinggi lemak. Metode penelitian menggunakan studi literatur. Database dalam studi literatur diperoleh dari Google Scholar, PubMed dan NCBI yang diambil secara Population, Intervention, Comparation, Output, Study, and Time (PICOST). Dari 5.166 artikel jurnal yang diperoleh, didapatkan 8 artikel jurnal yang membahas mengenai pengaruh pemberian ekstrak daun bayam merah (Amaranthus tricolor L.) terhadap kadar SGOT dan SGPT yang diberi diet tinggi lemak. Dosis $200 \mathrm{mg} / \mathrm{kgBB}$ dan $400 \mathrm{mg} / \mathrm{kgBB}$ dengan lama waktu pemberian 7 sampai 29 hari.
\end{abstract}

Kata Kunci : Diet Tinggi Lemak, Ekstrak Bayam Merah, Hiperlipidemia, NAFLD, SGOT, SGPT, Tikus Putih 


\section{PENDAHULUAN}

Hiperlipidemia merupakan penyakit progresif dan kronis yang menuntut gaya hidup dan perubahan pola makan, dengan kebutuhan potensial untuk pengobatan lipid tambahan (Hill dan Bordoni, 2020). Hiperlipidemia adalah kondisi peningkatan kolesterol total, rendah dan sangat rendah kepadatan lipoprotein tingkat kolesterol. Karena situasi ini terkait dengan gangguan metabolisme lemak (Firdous et al., 2020).

Menurut World Health Organization (WHO), telah melaporkan bahwa $40 \%$ dari populasi dunia menderita tingkat kolesterol plasma tinggi, yang mengkhawatirkan karena dianggap sebagai penyebab utama kematian (WHO, 2019) (Firdous et al., 2020). Prevalensi hiperlipidemia di Indonesia meningkat dari tahun ke tahun, pada tahun 2008 tercatat sebesar $35,1 \%$. Kemudian pada tahun 2013 meningkat menjadi 35,9\% (WHO, 2013). Peningkatan hiperlipidemia menjadi pemicu Non-Alcoholic Fatty Liver Desease (NAFLD) (Ghanaei et al., 2019).

NAFLD atau di sebut juga perlemakan hati non-alkoholik adalah akumulasi lemak dalam jumlah signifikan di dalam sel hepatosit melebihi $5 \%$ berat hati tanpa didahului riwayat mengonsumsi alkohol yang berlebihan sebelumnya, penggunaan obat-obatan steatogenik, atau kelainan herediter yang menyebabkan perlemakan hati, dan dibuktikan melalui pemeriksaan histologi ataupun modalitas pencitraan (Marina et al., 2017).

Prevalensi NAFLD berkisar antara 15$20 \%$ pada populasi dewasa di Amerika Serikat, Jepang, dan Italia. Diperkirakan $20 \%$ $30 \%$ diantaranya berada dalam fase lebih berat (steatohepatitis non alkoholik). Dalam laporan yang sama disebutkan pula bahwa $70 \%$ pasien diabetes mellitus tipe 2 mengalami perlemakan hati, sedangkan pada pasien dislipidemia angkanya sekitar 60\% (Hasan, 2014). NAFLD saat ini juga menjadi penyebab utama dari penyakit kronis hati di negara berkembang, di mana diperkirakan sepertiga populasi memiliki bukti adanya steatosis dari hasil pencitraan dengan mayoritas memiliki steatosis (7090\%). Kejadian NAFLD lebih sering pada laki-laki dibandingkan perempuan, selain itu NAFLD juga sering terjadi pada usia pertengahan sampai dengan usia lanjut dan pravalensinya terus meningkat seiring bertambahnya usia (Adiwinata, 2015).

Di Indonesia penelitian mengenai NAFLD masih belum banyak. Lesmana melaporkan 17 pasien steatohepatitis non alkoholik, rata-rata berumur 42 tahun dengan 29\% gambaran histologi hati menunjukan steatohepatitis di sertai fibrosis. Sebuah studi populasi dengan sampel cukup besar didapatkan prevalensi perlemakan hati non alkoholik sebesar 30,6\% (Hasan, 2014).

Kondisi NAFLD menyebabkan kerusakan sel hati sehingga menyebabkan peningkatan kadar enzim hati seperti SGOT dan SGPT (Prahastuti et al., 2020). Peningkatan SGOT dan SGPT disebabkan perubahan permiabilitas atau kerusakan dinding sel hati sehingga digunakan sebagai penanda gangguan integritas sel hati (hepatoseluler) (Rosida, 2016).

Serum Glutamic Oxalocetic Trasminase (SGOT) atau juga dinamakan Aspartate Amino Transminase (AST) merupakan enzim yang dijumpai dalam otot jatung dan hati, sementara dalam konsentrasi sedang dijumpai pada otot rangka, ginjal, dan pankreas. Konsentrasi rendah dijumpai dalam darah, kecuali jika terjadi cedera seluler, kemudian dalam jumlah banyak dilepaskan ke dalam sirkulasi (Nasution et al., 2016).

Penatalaksanaan NAFLD dengan modifikasi gaya hidup sehat yang terdiri dari diet, olahraga, dan penurunan berat badan, telah disarankan untuk mengobati pasien NAFLD. Data terbaik yang dihasilkan sampai saat ini menunjukan bahwa menurunkan berat badan secara keseluruhan adalah kunci perbaikan gambaran histopatologi Non Alcoholic Steato Hepatitis (NASH) (Chalasani et al., 2018).

Bayam merah (Amaranthus tricolor L.) merupakan salah satu spesies dari Kelompok tanaman bayam-bayaman (family Amaranthaceae). Pada umumnya merupakan tumbuhan berumur pendek yang tersebar di daerah-daerah tropika dan sub- tropika (Sulistyaningrum, 2014). Bayam merah memiliki kandungan seperti vitamin, niacin, mineral ( kalsium, mangan, fosfor, zat besi), serat, karotenoid, klorofil, alkaloid, flavonoid, saponin pada daun serta polifenon pada batang (Pradana et al., 2017).

Menurut Pradana et al. (2017) dikatakan bahwa ekstrak bayam merah memiliki aktivitas antioksidan yang mampu 
menghambat insisi dan dari reaksi rantai oksidasi karena mengandung senyawa flavonoid, kuersetin, tannin, dan saponin yang berpotensi sebagai terapi preventif perlemakan hati.

Berdasarkan uraian latar belakang di atas, peneliti ingin mengetahui pengaruh pemberian ekstrak daun bayam merah terhadap SGOT dan SGPT pada tikus putih (Rattus norvegicus) yang diberi diet tinggi lemak.

\section{METODE}

Penelitian ini merupakan penelitian kualitatif yang menggunakan metode studi literatur. Penentuan keyword pencarian literatur (search string) yang basisnya adalah dari Population, Intervention, Comparation, Output, Study, and Time (PICOST).

Penelitian ini dilaksanakan pada bulan Januari sampai bulan April 2021. Setelah mendapatkan persetujuan Komisi Etik Universitas Malahayati.

Penelitian dilakukan secara tidak langsung dengan mencari literatur-literatur ilmiah pada penelitian yang sudah ada sebelumnya dan akan dijadikan landasan pelaksanaan penelitian ini.

Pertanyaan yang baik akan membantu menentukan cakupan literatur dan membantu strategi mencari artikel, untuk itu PICOST perlu dilaporkan, terutama jika literatur yang dilakukan untuk menganalisis pengaruh pemberian ekstrak daun bayam merah (Amaranthus tricolor L.) terhadap kadar SGOT dan SGPT pada tikus putih (Rattus norvegicus) yang diberi diet tinggi lemak, seperti yang dijelaskan pada Tabel

Penggunaan Kata kunci merupakan hal penting dalam pencarian literatur. Kata kunci harus spesifik dan jelas. Pada bagian ini mahasiswa menjelaskan kata kunci yang akan digunakan dalam pencarian literatur, kata kunci yang digunakan pada penelitian ini adalah Ekstrak bayam merah, Kadar SGOT, Kadar SGPT, Tikus putih yang diberi diet tinggi lemak.

Database yang digunakan dalam penelusuran artikel dapat dilakukan minimal 2 database yaitu Google Scholar, PubMed, dan NCBI yang dipilih dengan memperhatikan kriteria inklusi dan kriteria eksklusi, didapatkan jumlah sampel sebanyak 8 sampel.

HASIL

Tabel 1 Penelitian Studi Literatur

\begin{tabular}{|c|c|c|c|c|c|c|c|c|}
\hline $\begin{array}{c}\text { No } \\
\cdot\end{array}$ & Judul & Penulis & $\begin{array}{c}\text { Tah } \\
\text { un }\end{array}$ & $\begin{array}{c}\text { Tujuan } \\
\text { Penelitian }\end{array}$ & $\begin{array}{c}\text { Lama } \\
\text { Pemb } \\
\text { erian } \\
\text { Ekstr } \\
\text { ak } \\
\text { (hari) }\end{array}$ & $\begin{array}{l}\text { P- } \\
\text { Val } \\
\text { ue }\end{array}$ & $\begin{array}{c}\text { Populasi } \\
\text { dan } \\
\text { Jumlah } \\
\text { Sampel }\end{array}$ & Hasil \\
\hline 1. & $\begin{array}{l}\text { Phytochemistry } \\
\text { and } \\
\text { hepatoprotectiv } \\
\text { e activity of } \\
\text { aqueous extract } \\
\text { of (Amaranthus } \\
\text { tricolor } \quad \text { L.) } \\
\text { roots }\end{array}$ & $\begin{array}{l}\text { Simran Aneja, } \\
\text { Manisha Vats, } \\
\text { Sushma } \\
\text { Anggarwal, } \\
\text { Satish } \\
\text { Sardana. }\end{array}$ & 2013 & $\begin{array}{l}\text { Evaluasi } \\
\text { efektivitas } \\
\text { ekstrak air akar } \\
\text { bayam merah } \\
\text { untuk } \\
\text { perlindungan } \\
\text { terhadap } \\
\text { overdosis } \\
\text { parasetamol } \\
\text { (PCM) } \\
\text { diinduksi } \\
\text { hepatotoksisitas }\end{array}$ & 7 & $\begin{array}{c}<0,0 \\
5\end{array}$ & $\begin{array}{l}30 \text { ekor } \\
\text { tikus } \\
\text { dibagi } \\
\text { kedalam } 5 \\
\text { kelompok. } \\
\text { Setiap } \\
\text { kelompok } \\
\text { terdiri dari } \\
6 \quad \text { ekor } \\
\text { tikus. }\end{array}$ & $\begin{array}{l}\text { Ekstrak air akar } \\
\text { bayam merah } \\
\text { yang diinduksi } \\
\text { paracetamol } \\
\text { dapat } \\
\text { menurunkan } \\
\text { kadar SGPT, } \\
\text { SGOT, ALP, } \\
\text { dan TB, yang } \\
\text { didukung oleh } \\
\text { studi } \\
\text { histopatologi } \\
\text { hati. Ekstrak air } \\
\text { akar bayam } \\
\text { merah } \\
\text { berpotensi } \\
\text { efektif dalam } \\
\text { mengobati } \\
\text { liver. }\end{array}$ \\
\hline
\end{tabular}




\begin{tabular}{|c|c|c|c|c|c|c|c|c|}
\hline 2. & $\begin{array}{l}\text { Potential of } \\
\text { Red Spinach } \\
\text { Leaves } \\
\text { Ethanolic } \\
\text { Extract } \\
\text { (Amaranthus } \\
\text { tricolor L.) as a } \\
\text { Complementary } \\
\text { Therapy For } \\
\text { Hiperlipidemia: } \\
\text { Study inVivo of } \\
\text { Histopathologic } \\
\text { and Activity of } \\
\text { Alanin } \\
\text { Aminotransfera } \\
\text { se (ALT). }\end{array}$ & $\begin{array}{l}\text { Dimas Adhi } \\
\text { Pradana, Irna } \\
\text { Destya } \\
\text { Anggriani, \& } \\
\text { Tri Ratna } \\
\text { Setyaningrum }\end{array}$ & 2016 & $\begin{array}{l}\text { Untuk } \\
\text { mengetahui } \\
\text { potensi ekstrak } \\
\text { etanol bayam } \\
\text { merah sebagai } \\
\text { pengobatan } \\
\text { hiperlipidemia } \\
\text { berdasarkan } \\
\text { histopatologi } \\
\text { dan aktivitas } \\
\text { SGOT. }\end{array}$ & 17 & $\begin{array}{c}<0,0 \\
5\end{array}$ & $\begin{array}{l}24 \text { ekor } \\
\text { tikus } \\
\text { dibagi } \\
\text { kedalam } 6 \\
\text { kelompok. } \\
\text { Setiap } \\
\text { kelompok } \\
\text { terdiri dari } \\
4 \quad \text { ekor } \\
\text { tikus. }\end{array}$ & $\begin{array}{lr}\text { Ekstrak } & \\
\text { etanolik bayam } \\
\text { merah dosis } \\
\text { 400mg / } \\
\text { tikus rBB } \\
\text { diinduksi yang } \\
\text { dengan } \\
\text { simvastatin } \\
\text { dapat } \\
\text { menurunkan } \\
\text { kadar SGOT } \\
\text { hingga 31.57 } \\
\text { U1-1. }\end{array}$ \\
\hline 3. & $\begin{array}{l}\text { In-vitro and } \\
\text { In-vivo } \\
\text { Hypolipidemic } \\
\text { Activity of } \\
\text { Spinach Roots } \\
\text { and Flowers }\end{array}$ & $\begin{array}{l}\text { Mona Hafez } \\
\text { Hettaa, Abeer } \\
\text { Sayed } \\
\text { Moawadb, } \\
\text { Manal Abdel- } \\
\text { Aziz Hamedc } \\
\text { and Ahmed } \\
\text { Ismail Sabria }\end{array}$ & 2017 & $\begin{array}{l}\text { Mengkorelasika } \\
\mathrm{n} \text { kandungan } \\
\text { flavaniod dan } \\
\text { lipod akar dan } \\
\text { bunga bayam } \\
\text { dengan potensi } \\
\text { hipolipidemik. }\end{array}$ & 28 & $\begin{array}{c}<0,0 \\
5\end{array}$ & $\begin{array}{l}40 \text { ekor } \\
\text { tikus } \\
\text { dibagi } \\
\text { kedalam } \\
5 \\
\text { kelompo } \\
\text { k. Setiap } \\
\text { kelompo } \\
\text { k terdiri } \\
\text { dari } 8 \\
\text { ekor } \\
\text { tikus. }\end{array}$ & 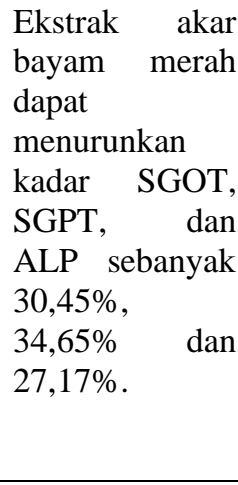 \\
\hline 4. & $\begin{array}{l}\text { Aktivitas } \\
\text { Ekstrak } \\
\text { Etanolik Bayam } \\
\text { Merah } \\
\text { (Amaranthus } \\
\text { tricolor L) } \\
\text { Terstandar } \\
\text { sebagai Upaya } \\
\text { Preventif } \\
\text { Steatosis: Studi } \\
\text { in Vivo }\end{array}$ & $\begin{array}{l}\text { Dimas Adhi } \\
\text { Pradana, } \\
\text { Deasy Wulan } \\
\text { Dwiratna \& } \\
\text { Sitarina } \\
\text { Widyarini }\end{array}$ & 2017 & $\begin{array}{l}\text { Untuk } \\
\text { mengetahui } \\
\text { pemberian } \\
\text { ekstrak etanolik } \\
\text { bayam merah } \\
\text { terstandar } \\
\text { sebagai terapi } \\
\text { preventif.terhad } \\
\text { ap peningkatan } \\
\text { kadar SGOT } \\
\text { dan aktivitas } \\
\text { ekstrak etanolik } \\
\text { bayam merah. }\end{array}$ & 67 & $\begin{array}{c}<0,0 \\
5\end{array}$ & $\begin{array}{l}30 \text { tikus } \\
\text { dibagi ke } \\
\text { dalam } 6 \\
\text { kelompok. } \\
\text { Setiap } \\
\text { kelompk } \\
\text { terdiri dari } \\
5 \quad \text { ekor } \\
\text { tikus. }\end{array}$ & $\begin{array}{l}\text { Ekstrak bayam } \\
\text { merah } \\
\text { terstandar dosis } \\
200 \mathrm{mg} / \mathrm{kgBB} \text {, } \\
400 \mathrm{mg} / \mathrm{kgBB} \\
\mathrm{dan} r \\
\mathrm{mg} / \mathrm{kgBB} \text { dapat } \\
\text { mempertahanka } \\
\mathrm{n} \text { kadar SGOT } \\
\text { dalam rentang } \\
\text { normal dan } \\
\text { memperlihatka } \\
\mathrm{n} \text { gambaran } \\
\text { histopatologi } \\
\text { hati yang } \\
\text { normal. Ekstrak } \\
\text { etanolik bayam } \\
\text { merah } \\
\text { terstandar } \\
\text { berpotensi } \\
\text { sebagai terapi } \\
\text { preventif } \\
\text { steatosis. }\end{array}$ \\
\hline 5. & $\begin{array}{l}\text { Cardioprotectiv } \\
\text { e Effect of } \\
\text { (Amaranthus } \\
\text { tricolor } \\
\text { Extract in } \\
\text { Isoprenaline } \\
\text { Induced } \\
\text { Myocardial } \\
\text { Damage in }\end{array}$ & \begin{tabular}{l}
\multicolumn{2}{l}{ Kamrun } \\
Nahar, Fariha \\
Kabir, Priota \\
Islam, Md. \\
Mizanur \\
Rahman, \\
Md.
\end{tabular} & 2018 & $\begin{array}{l}\text { Untuk } \\
\text { menyelidiki } \\
\text { efek dari } \\
\text { ekstrak bayam } \\
\text { merah pada } \\
\text { stres oksidatif } \\
\text { yang diinduksi } \\
\text { isoproterenol, } \\
\text { fibrosis, dan }\end{array}$ & 14 & $\begin{array}{c}<0,0 \\
5\end{array}$ & $\begin{array}{l}6 \\
\text { kelompok. }\end{array}$ & $\begin{array}{l}\text { Pemberian } \\
\text { ekstrak bayam } \\
\text { merah dosis } 50 \\
\text { mg/kgBB yang } \\
\text { diinduksi ISO } \\
\text { lebih } \\
\text { meningkatkan } \\
\text { kadar SGOT } \\
\text { SGPT }\end{array}$ \\
\hline
\end{tabular}




\begin{tabular}{|c|c|c|c|c|c|c|c|c|}
\hline & $\begin{array}{l}\text { Ovariectomized } \\
\text { Rats }\end{array}$ & & & $\begin{array}{ll}\text { kerusakan } & \\
\text { miokard pada } \\
\text { tikus yang } \\
\text { diovariektomi. }\end{array}$ & & & & $\begin{array}{l}\text { dibandingkan } \\
\text { pemberian } \\
\text { dosis } \\
\text { 100mg/kgBB } \\
\text { dan } \\
\text { 200mg/kgBB } \\
\text { yang diinduksi } \\
\text { ISO. Kadar } \\
\text { SGOT dan } \\
\text { SGPT } \\
\text { mengalami } \\
\text { penurunan } \\
\text { ketika diberi } \\
\text { atenolol dosis } \\
\text { 50mg/kgBB }\end{array}$ \\
\hline 6. & $\begin{array}{l}\text { Exploring The } \\
\text { Potential } \\
\text { Effects of } \\
\text { (Amaranthus } \\
\text { tricolor L.) in } \\
\text { Dyslipidemia } \\
\text { and } \\
\text { Dyslipidemia } \\
\text { Induced } \\
\text { Complications } \\
\text { In Rats }\end{array}$ & $\begin{array}{l}\text { Lalit Singh, } \\
\text { Sokindra } \\
\text { Kumar and } \\
\text { Najam } \\
\text { Khan }\end{array}$ & 2019 & $\begin{array}{l}\text { Untuk } \\
\text { pai skrining } \\
\text { fitokimia awal, } \\
\text { toksisitas oral } \\
\text { akut, } \\
\text { aktivitas } \\
\text { antioksidan, dan } \\
\text { untuk } \\
\text { mengevaluasi } \\
\text { Antihiperlipide } \\
\text { mik dari ekstrak } \\
\text { bayam merah. }\end{array}$ & 29 & $\begin{array}{c}<0,0 \\
5\end{array}$ & $\begin{array}{l}56 \text { ekor } \\
\text { tikus, } \\
\text { dibagi } \\
\text { kedalam } \\
7 \\
\text { kelompok. } \\
\text { Setiap } \\
\text { kelompok } \\
\text { terdiri dari } \\
8 \quad \text { ekor } \\
\text { tikus. }\end{array}$ & $\begin{array}{l}\text { Pada tikus } \\
\text { hiperlipidemia } \\
\text { yang dinduksi } \\
\text { kolesterol, } \\
\text { setelah diberi } \\
\text { yang diberi } \\
\text { ekstrak bayam } \\
\text { merah } \\
\text { mengalami } \\
\text { penurunan } \\
\text { kadar SGOT } \\
\text { dan SGPT. }\end{array}$ \\
\hline 7. & $\begin{array}{l}\text { Ameliorative } \\
\text { Effect of } \\
\text { Spinach on } \\
\text { Non- Alcoholic } \\
\text { Fatty Liver } \\
\text { Disease } \\
\text { Induced in Rats } \\
\text { by a High-Fat } \\
\text { Diet }\end{array}$ & $\begin{array}{l}\text { Laura Inés } \\
\text { Elvira-Torales, } \\
\text { Gala Martín- } \\
\text { Pozuelo, Rocío } \\
\text { González- } \\
\text { Barrio, } \\
\text { Inmaculada } \\
\text { Navarro- } \\
\text { González, } \\
\text { Francisco-José } \\
\text { Pallarés, } \\
\text { Marina } \\
\text { Santaella, } \\
\text { Javier García- } \\
\text { Alonso, Ángel } \\
\text { Sevilla and } \\
\text { María Jesús } \\
\text { Periago- } \\
\text { Castón. }\end{array}$ & 2019 & $\begin{array}{l}\text { Mengevaluasi } \\
\text { efek } \\
\text { karotenoid } \\
\text { makanan dari } \\
\text { bayam pada } \\
\text { biomarker } \\
\text { inflamasi dan } \\
\text { stres oksidatif, } \\
\text { profil lipid hati, } \\
\text { dan } \\
\text { transkriptomik } \\
\text { hati dan profil } \\
\text { metabolomik } \\
\text { pada tikus } \\
\text { Sprague- } \\
\text { Dawley dengan } \\
\text { steatosis yang } \\
\text { disebabkan oleh } \\
\text { diet tinggi } \\
\text { lemak. }\end{array}$ & 35 & $\begin{array}{c}<0,0 \\
5\end{array}$ & $\begin{array}{l}44 \quad \text { ekor } \\
\text { tikus } \\
\text { dibagi } \\
\text { kedalam } 6 \\
\text { kelompok. } \\
2 \\
\text { kelompok } \\
\text { masing- } \\
\text { masing } 6 \\
\text { ekor tikus } \\
\text { dan } 4 \\
\text { kelompok } \\
\text { masing- } \\
\text { masing } 8 \\
\text { ekor tikus. }\end{array}$ & 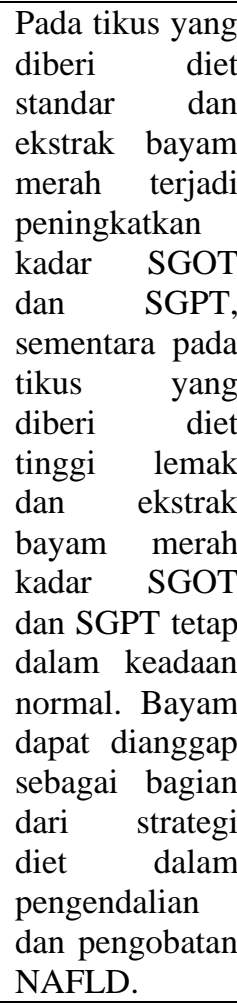 \\
\hline 8. & $\begin{array}{l}\text { Antidiabetic } \\
\text { and } \\
\text { Antihyperchol } \\
\text { esterolem ic } \\
\text { Activities } \\
\text { of Decoction } \\
\text { of }\end{array}$ & $\begin{array}{l}\text { Md. Siddiqul } \\
\text { Islam }\end{array}$ & 2020 & $\begin{array}{l}\text { Studi saat ini } \\
\text { menunjukkan } \\
\text { bahwa rebusan } \\
\text { bayam merah } \\
\text { dapat } \\
\text { digunakan } \\
\text { untuk }\end{array}$ & 14 & $\begin{array}{c}<0,0 \\
5\end{array}$ & $\begin{array}{l}\text { Sebanyak } \\
25 \quad \text { ekor } \\
\text { tikus } \\
\text { dibagi } \\
\text { kedalam } 5 \\
\text { kelompok. } \\
\text { Setiaap } \\
\end{array}$ & $\begin{array}{l}\text { Pemberian } \\
\text { ekstrak bayam } \\
\text { merah yang } \\
\text { diinduksi } \\
\text { aloksan, dapat } \\
\text { mempertahanka } \\
\text { n kadar SGOT }\end{array}$ \\
\hline
\end{tabular}




\begin{tabular}{llll}
\hline (Amaranthus & pengobatan & kelompok dan & SGPT, \\
tricolor L.) on & diabetes & terdiri dari & serta protein \\
Alloxan- & mellitus serta & 5 ekor total tap & tetap \\
induced & untuk & tikus. & dalam keadaan \\
Diabetic Rats. & pengobatan & normal. \\
& hiperkolesterole & & \\
& mia. & & \\
\hline
\end{tabular}

Sumber : Data Primer Diolah Peneliti

Berdasarkan Tabel 1 terdapat beberapa penelitian yang menggunakan komposisi diet tinggi lemak untuk menaikkan kadar SGOT dan SGPT. Dapat dilihat pada tabel berikut.

Tabel 2 Induksi Komponen Makanan Diet Tinggi Lemak.

\begin{tabular}{|c|c|c|c|c|c|c|}
\hline No. & Nama (tahun) & $\begin{array}{l}\text { Lama } \\
\text { waktu } \\
\text { (hari) }\end{array}$ & $\begin{array}{l}\text { Komponen diet } \\
\text { tinggi lemak }\end{array}$ & $\begin{array}{c}\text { Kadar } \\
\text { SGOT } \\
\text { setelah } \\
\text { diinduksi } \\
\text { diet tinggi } \\
\text { lemak(U/L) }\end{array}$ & $\begin{array}{c}\text { Kadar } \\
\text { SGPT } \\
\text { setelah } \\
\text { diinduksi } \\
\text { diet tinggi } \\
\text { lemak } \\
\text { (U/L) }\end{array}$ & Sig. \\
\hline 1. & Aneja et al. (2013) & 7 & - & 336.1 & 347.0 & $<0.05$ \\
\hline 2. & Pradana et al. (2016) & 16 & $\begin{array}{l}\text { Diinduksi lipid } \\
\text { dengan poloxamer } \\
1000 / \mathrm{kgBB} .\end{array}$ & - & 93.76 & $<0.05$ \\
\hline 3. & Hetta et al. (2017) & 14 & $\begin{array}{l}\text { Diet } \quad \text { Kolesterol } \\
\text { dengan dosis } 30 \mathrm{mg} \text {. }\end{array}$ & 54.41 & 66.06 & $<0.05$ \\
\hline 4. & Pradana et al. (2017) & 59 & $\begin{array}{l}\text { Minyak babi murni } \\
\text { dan kuning telur } \\
\text { bebek. }\end{array}$ & - & 123.98 & 0.000 \\
\hline 5. & Nahar et al. (2017) & 14 & - & 38 & 25 & $<0.05$ \\
\hline 6. & Singh et al. (2019) & 21 & $\begin{array}{l}\text { Diet aterogenik } \\
\text { (kolesterol } 2 \% \text {, kolin } \\
\text { klorida } 1 \% \text { dan } \\
\text { lemak babi } 2 \% \text { ). }\end{array}$ & 85.58 & 42.25 & $<0.01$ \\
\hline 7. & Torales et al. (2019) & 63 & $\begin{array}{l}\text { Diet tinggi lemak } \\
\text { (lemak babi 150g) }\end{array}$ & 151.10 & 47.95 & $<0.05$ \\
\hline 8. & Islam. (2020) & 14 & - & 28.5 & 29.5 & $<0.05$ \\
\hline
\end{tabular}

Sumber : Data Primer Diolah Peneliti

Selain diinduksi komponen makanan diet tinggi lemak, untuk menaikan kadar SGOT dan SGPT. Kemudian diberikan ekstrak bayam merah untuk menurunkan kadar SGOT dan SGPT. Berikut kandungan dan mekanisme ekstrak bayam merah.

Tabel 3 Karakteristik Kandungan Amaranthus tricolor L. Terhadap Kadar SGOT dan SGPT

No. Penulis (tahun) $\quad$ Intervensi $\quad$ Mekanisme


1. Hetta et al. Senyawa fenolik Bertambahnya asam lemak bebas di dalam hati akan menimbulkan (2017) Pradana (flavanoid). peningkatan oksidasi dan peningkatan radikal bebas. Kemudian et al. (2017) mampu menghambat insisi dari rantai oksidasi, radikal bebas. Islam et al. (2020) Sehingga kadar SGOT dan SGPT menurun.

2. Pradana et al. Kuersetin (2017)

Kuerstetin sebagai antioksidan yang dapat menghambat sekresi apo-B 100 pada sel $\mathrm{CaCO}_{2}$ serta dapat menurunkan aktivitas MTP yang berperan dalam pembentukan kolesterol dan trigliserida dan menghambat aktivitas enzim HMG-KoA reduktase, yaitu enzim yang berperan dalam pembentukan kolesterol. Selain itu sebagai antioksidan yang dapat menekan radikal bebas.

3. Pradana et al. Tanin (2017)

Menghambat penyerapan lemak di usus dengan cara bereaksi dengan dengan protein mukosa dan sel epitel usus dan saponin yang akan berikatan dengan ikatan kompleks yang berasal dari makanan dengan cara meningkatkan pengikatan kolesterol oleh serat sehingga kolesterol tidak dapat diserap oleh usus.

4. Nahae et al., Saponin, Beta-cyanin agen antioksidan utama dari daun tanaman sebagai (2018) alkaloid, fenolat, aktivitas farmakologis, seperti efek anti tumor, aktivitas anti-ulkus, dan oksalat. aktivitas hepatoprotektif ekstrak bayam merah digunakan sebagai diuretik untuk bertindak melawan radang luar dan juga digunakan sebagai pengobatan digangguan kandung kemih

Sumber : Data Primer Diolah Peneliti

Tabel 4 Pemberian Dosis Ekstrak Bayam Merah

\begin{tabular}{|c|c|c|c|c|c|c|}
\hline No. & $\begin{array}{c}\text { Nama } \\
\text { (tahun) }\end{array}$ & $\begin{array}{l}\text { Lama } \\
\text { waktu } \\
\text { (hari) }\end{array}$ & Dosis ekstrak bayam merah & $\begin{array}{c}\text { SGOT } \\
\text { setelah } \\
\text { diberi } \\
\text { ekstrak } \\
\text { bayam } \\
\text { merah } \\
(\mathrm{U} / \mathrm{L})\end{array}$ & $\begin{array}{c}\text { SGPT } \\
\text { setelah } \\
\text { diberi } \\
\text { ekstrak } \\
\text { bayam } \\
\text { merah } \\
\text { (U/L) }\end{array}$ & Sig. \\
\hline \multirow[t]{2}{*}{1.} & Aneja et & 7 & $200 \mathrm{mg} / \mathrm{kgBB}$ & 260.4 & 270.7 & $<0.05$ \\
\hline & & & $400 \mathrm{mg} / \mathrm{kgBB}$ & 244.9 & 264.9 & $<0.05$ \\
\hline \multirow[t]{2}{*}{2.} & Pradana & 17 & $400 \mathrm{mg} / \mathrm{kgBB}$ & - & 32.32 & $<0.05$ \\
\hline & $\begin{array}{l}\text { et al. } \\
(2016)\end{array}$ & & $400 \mathrm{mg} / \mathrm{kgBB}+$ Simvastatin & - & 31.57 & $<0.05$ \\
\hline \multirow[t]{2}{*}{3.} & Hetta et & 28 & 400mg/kgBB (Akar bayam) & 37.84 & 43.17 & $<0.05$ \\
\hline & $\begin{array}{l}\text { al. } \\
(2017)\end{array}$ & & 400mg/kgBB (Bunga bayam) & 38.33 & 48.19 & $<0.05$ \\
\hline \multirow[t]{3}{*}{4.} & Pradana & 67 & $200 \mathrm{mg} / \mathrm{kgBB}$ & - & 69.54 & 0.042 \\
\hline & et al. & & $400 \mathrm{mg} / \mathrm{kgBB}$ & - & 73.63 & 0.036 \\
\hline & $(2017)$ & & $800 \mathrm{mg} / \mathrm{kgBB}$ & - & 68.42 & 0.039 \\
\hline \multirow[t]{3}{*}{5.} & Nahar et & 14 & $50 \mathrm{mg} / \mathrm{kgBB}$ & 28 & 22 & $<0.05$ \\
\hline & & & $100 \mathrm{mg} / \mathrm{kgBB}$ & 26 & 20 & $<0.05$ \\
\hline & $(2017)$ & & $200 \mathrm{mg} / \mathrm{kgBB}$ & 25 & 18 & $<0.05$ \\
\hline \multirow[t]{4}{*}{6.} & Singh et & 29 & $200 \mathrm{mg} / \mathrm{kgBB}$ (Ethanolik) & 65.24 & 76.82 & $<0.01$ \\
\hline & & & $400 \mathrm{mg} / \mathrm{kgBB}($ Ethanolik$)$ & 58.32 & 56.32 & $<0.05$ \\
\hline & (2019) & & 200mg/kgBB (Air) & 72.54 & 72.54 & $<0.05$ \\
\hline & & & $400 \mathrm{mg} / \mathrm{kgBB}$ (Air) & 60.34 & 60.34 & $<0.05$ \\
\hline \multirow[t]{4}{*}{7.} & Torales & 35 & $5 \%$ bayam merah & 88.28 & 28.95 & $<0.05$ \\
\hline & et al. & & $2.5 \%$ bayam merah & 106.1 & 34.40 & $<0.05$ \\
\hline & (2019) & & $\begin{array}{l}5 \% \text { bayam merah }+ \\
\text { diet tinggi lemak }\end{array}$ & 139.2 & 45.43 & $<0.05$ \\
\hline & & & $\begin{array}{l}2.5 \% \text { bayam merah+ } \\
\text { diet tinggi lemak }\end{array}$ & 142.7 & 44.30 & $<0.05$ \\
\hline
\end{tabular}




\begin{tabular}{llllll}
\hline 8. & Islam. 14 & Diabetic+bayam merah & 41.4 & 42.2 & $<0.05$ \\
& $(2020)$ & & 38.2 & 40.7 & $<0.05$ \\
\hline
\end{tabular}

Sumber : Data Primer Diolah Peneliti

Ekstrak Daun Bayam Merah Pada Dosis 200mg/kgBB

Jurnal Aneja et al. (2013); Nahar et al. (2017); Sing et al. (2019)

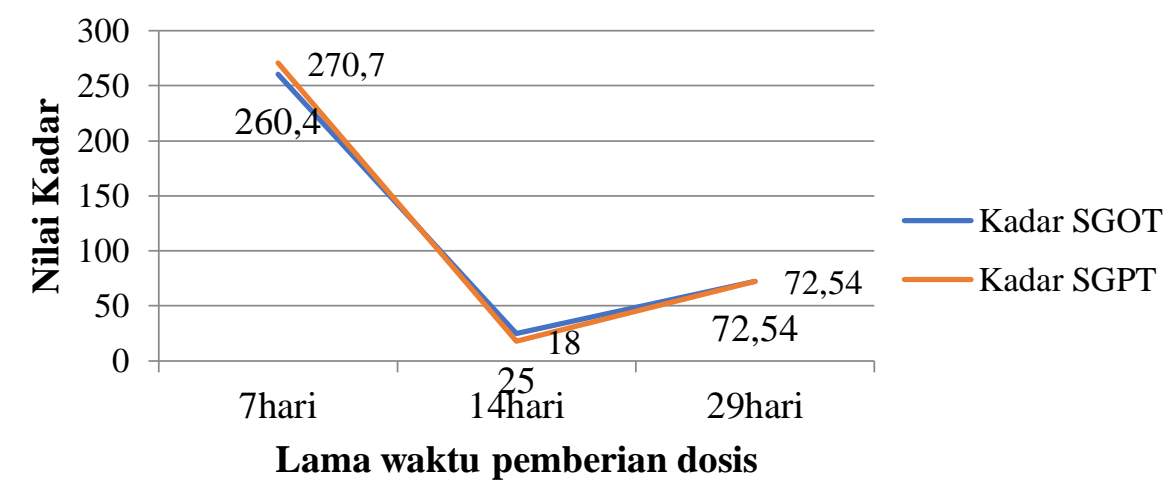

Gambar 1 Nilai Kadar SGOT Setelah Diberi Ekstrak Bayam Merah Dosis 200 mg/kgBB Sumber : Data Diolah Oleh Peneliti

Ekstrak Daun Bayam Merah Dengan Dosis 400mg/kgBB Jurnal Aneja et al. (2013); Sih et al. (2019)

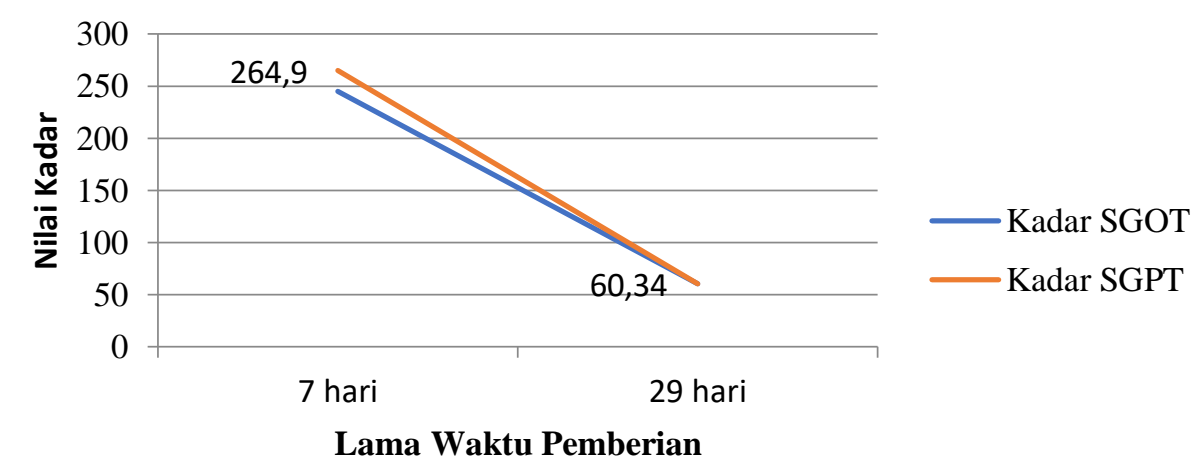

Gambar 2 Nilai Kadar SGOT Setelah Diberi Ekstrak Bayam Merah Dosis 400 mg/kgBB Sumber : Data Diolah Oleh Peneliti 


\section{PEMBAHASAN}

Diet tinggi lemak merupakan pola diet dengan aturan pola makan yang tinggi mengkonsumsi lemak, namun besarnya kenaikan berat badan tergantung kepada jenis dan komposisi makanan yang dikonsumsi. Diet tinggi lemak mampu memberikan peningkatan kadar lemak tubuh, kolesterol tubuh maupun menaikkan berat badan secara signifikan.

Pada hewan, komposisi makanan diet tinggi lemak dapat dibuat dari kombinasi berbagai makanan yang mengandung lemak tinggi. Pada beberapa penelitian, terdapat beberapa jenis makanan diet tinggi lemak yang di ujikan kepada tikus galur wistar dengan penambahan induksi pakan yang mampu menekan pertumbuhan perlemakan hati pada tikus galur wistar.

Menurut Pradana et al. (2016) pemberian diet tinggi lemak dengan komposisi (lipid dengan poloxamer 1000 / $\mathrm{kgBB})$ pemberian dilakukan selama 16 hari, dapat meningkatkan kadar SGPT dengan nilai kadar 93,76U/L. Menurut Hetta et al. (2017) pemberian diet tinggi lemak dengan komposisi (kolesterol dosis $30 \mathrm{mg}$ ) yang diinduksi obat fenofibrate dosis $50 \mathrm{mg} / \mathrm{kgBB}$ pemberian dilakukan selama 14 hari, dapat meningkatkan kadar SGOT dan SGPT dengan nilai kadar 54,41U/L dan 66,06U/L.

Menurut Pradana et al. (2017) pemberian diet tinggi lemak dengan komposisi minyak babi murni dan kuning telur bebek yang diinduksi simvastatin $0,9 \mathrm{mg} / \mathrm{kgBB}$ pemberian dilakukan selama 59 hari, dapat meningkatkan kadar SGPT dengan nilai kadar 123,98U/L. Menurut Sing et al. (2019) pemberian diet tinggi lemak dengan komposisi (diet aterogenik yaitu kolesterol $2 \%$, kolin klorida $1 \%$ dan lemak babi $2 \%$ ), pemberian dilakukan selama 21 hari, dapat meningkatkan kadar SGOT dan SGPT dengan nilai kadar $85,58 \mathrm{U} / \mathrm{L}$ dan 42,25U/L. Menurut Torales et al. (2019) pemberian diet tinggi lemak dengan komposisi (lemak babi 150g) yang diinduksi keratonoid pemberian dilakukan selama 63 hari, dapat meningkatkan kadar SGOT dan SGPT dengan nilai kadar 151,10U/L dan 47,95U/L.

Menurut Aneja et al. (2013); Nahar et al. (2017); dan Islam, (2020). Bukan hanya menggunakan komposisi induksi diet tinggi lemak, tetapi dapat diinduksi langsung dengan menggunakan obat untuk meningkatkan kadar SGOT dan SGPT. Menurut Aneja et al. (2013) pemberian paracetamol selama 7 hari dapat meningkatkan kadar SGOT dan SGPT pada tikus, dengan nilai kadar 336,1U/L dan 347,0U/L. Menurut Nahar et al. (2017) pemberian Isoprotereno (ISO) dengan dosis $50 \mathrm{mg}$, pemberian selama 14 hari dapat meningkatkan kadar SGOT dan SGPT pada tikus, dengan nilai kadar 38U/L dan 28U/L. Menurut Islam, (2020) pemberian aloksan dengan dosis $50 \mathrm{mg}$, pemberian selama 14 hari dapat meningkatkan kadar SGOT dan SGPT pada tikus, dengan nilai kadar 28,5U/L dan 29,5U/L.

Bayam merah (Amaranthus tricolor L.) merupakan salah satu spesies dari kelompok tanaman bayam-bayaman (family Amaranthaceae). Pada umumnya merupakan tumbuhan berumur pendek yang tersebar di daerah-daerah tropika dan sub- tropika (Pradana et al., 2017). Menurut Aneja et al. (2013) Ekstrak air akar bayam merah mengandung senyawa alkaloid, karbohidrat, flavanoid, asam amino, protein, minyak tetap, saponin dan tanin, dan senyawa fenolik.

Daun Bayam merah memiliki kandungan seperti vitamin, niacin, mineral (kalsium, mangan, fosfor, zat besi), serat, karotenoid, klorofil, alkaloid, flavonoid, saponin serta polifenon pada batang (Pradana et al., 2017). Bayam merah dilaporkan kaya protein, vitamin $\mathrm{C}$, karotenoid, serat makanan, berbagai mineral seperti magnesium, kalsium, seng, dan zat besi (Islam, 2020).

Menurut Nahar et al. (2018). Bayam merah mengandung sejumlah senyawa tinggi saponin, alkaloid, fenolat, dan oksalat, tinggi vitamin $\mathrm{C}$, Vitamin $\mathrm{A}$, 
Vitamin B6, riboflavin dan foliat. Dari 8 jurnal terkait kandungan ekstrak bayam sangat banyak. Dan terkait pembuatan ekstrak bukan hanya menggunakan daunnya saja, ada yang menggunakan akar dan bunga.

Efek potensial merupakan akibat apa saja yang dihasilkan ketika diberikan suatu zat kedalam objek yang akan diteliti. Dalam hal ini, potensial efek yang dimaksud adalah akibat yang dihasilkan dari pemberikan ekstrak daun bayam merah terhadap kadar SGOT dan SGPT tikus jantan galur wistar yang diinduksi diet tinggi lemak.

Flavanoid ditemukan pada ekstrak bayam merah yang berperan sebagai antioksidan yang dapat menekan pelepasan radikal yang reaktif sehingga menekan terjadinya kerusakan endotel dengan menghambat inisiasi dari reaksi rantai oksidasi, mencegah makin banyaknya makrofag Berdasarkan parameter histopatologi dan parameter SGOT dan SGPT (Pradana et al., 2017).

Ekstrak etanolik bayam merah mampu mencegah terjadinya perlemakan hati dan kenaikan kadar SGPT karena mengandung senyawa aktif yaitu kuersetin, tanin dan saponin. Mekanismenya berawal dari stres oksidatif yang memicu peroksidasi lipid akibat kerusakan membran plasma. Kerusakan atau peningkatan permeabilitas membran hepatosit akan mengakibatkan destruksi mitokondria, retikulum endoplasmik, inaktivasi enzim, denaturasi protein, serta masuknya enzim (Aminotransaminase) termasuk SGPT.

Bila terjadi nekrosis sel yang menyebabkan destruksi mitokondria dan retikulum endoplasmik tempat enzim tersebut, maka enzim tersebut akan masuk ke dalam sirkulasi darah sehingga kadar SGPT dalam darah meningkat. Asupan diet tinggi lemak dalam jangka waktu yang lama akan menyebabkan terjadinya steatosis dalam sel hati. Trigliserida yang dibentuk dalam hati akan mengalami dua hal yaitu disimpan dalam droplet lemak yang mengakibatkan steohepatis atau dikemas bersama apoprotein B (apo-b) dan disekresikan kedalam sirkulasi dalam bentuk Very Low Density Lipoprotein (VLDL) (Hetta et al., 2017; Pradana et al., 2017; Islam et al., 2020).

Kuersetin merupakan antioksidan yang dapat menghambat sekresi apo-B 100 pada sel $\mathrm{CaCO}$ serta dapat menurunkan aktivitas MTP yang berperan dalam pembentukan kolesterol dan trigliserida. Kuersetin juga dapat menghambat aktivitas enzim HMG-KoA reduktase, yaitu enzim yang berperan dalam pembentukan kolesterol selain itu juga sebagai antioksidan yang dapat menekan radikal bebas (Pradana et al., 2017).

Tanin dapat menghambat penyerapan lemak di usus dengan cara bereaksi dengan dengan protein mukosa dan sel epitel usus dan saponin yang akan berikatan dengan ikatan kompleks yang berasal dari makanan dengan cara meningkatkan pengikatan kolesterol oleh serat sehingga kolesterol tidak dapat diserap oleh usus. Selain itu (Pradana et al., 2017).

Ekstrak bayam merah mengandung beta-cyanin agen antioksidan utama dari daun tanaman sebagai aktivitas farmakologis, seperti efek anti tumor, aktivitas anti-ulkus, aktivitas hepatoprotektif ekstrak bayam merah digunakan sebagai diuretik untuk bertindak melawan radang luar dan juga digunakan sebagai pengobatan digangguan kandung kemih karena mengandung sejumlah tinggi saponin, alkaloid, fenolat, dan oksalat. Telah dilaporkan bahwa bayam merah mengandun tinggi vitamin $\mathrm{C}$ dan $\mathrm{A}$, Vitamin B6, riboflavin dan foliat (Nahar et al., 2018).

Ekstrak air akar bayam merah secara signifikan mencegah perubahan fisik, biokimia, histologis, dan fungsional diinduksi oleh parasetamol di hati. Ekstrak menunjukkan efek hepatoprotektif yang signifikan yang dibuktikan dengan penurunan aktivitas enzim serum seperti SGPT, SGOT, ALP, dan TB, yang didukung oleh studi histopatologi hati. Ekstrak air menunjukkan aktivitas 
hepatoprotektif yang signifikan sebanding dengan silymarin obat standar serta hepatotoksin (Aneja et al., 2020).

Varian Dosis dan Lama Waktu Pemberian Ekstrak Bayam Merah untuk menurunkan kadar SGOT dan SGPT pada tikus dilakukan pemberian terapi dengan ekstrak bayam merah dengan berbagai dosis. Pemberian dosis yang berbeda mampu memberikan efek yang berbeda pula terhadap penurunan kadar SGOT dan SGPT pada tikus jantan galur wistar.

Dari 8 jurnal terdapat varian pemberian dosis ekstrak air akar bayam merah. Menurut penelitian Aneja et al. (2013) dosis 200mg/kg, dan 400mg/kg pemberian selama 7 hari. Dosis pertama pada 0 jam, dosis kedua pada 24 jam dapat menurunkan kadar SGOT dan SGPT dengan nilai kadar 260,4U/L dan 270,7U/L. Hasil penelitian menunjukkan ekstrak air akar bayam merah memiliki hepatoprotektif dikaitkan dengan antioksidan yang terdapat pada ekstrak.

Menurut Pradana et al. (2016) pemberian ekstrak bayam merah dosis $400 \mathrm{mg} / \mathrm{kg}$ pemberian selama 17 hari dapat menurunkan kadar SGPT dengan nilai kadar 32,32U/L. Kemudian pemberian ekstrak bayam merah dosis $400 \mathrm{mg} / \mathrm{kg}$ yang diinduksi simvastatin pemberian dilakukan selama 17 hari dapat menurunkan kadar SGPT dengan nilai kadar 31,57U/L. Kelompok ekstrak bayam merah dosis $200 \mathrm{mg} / \mathrm{kgBB}, 400 \mathrm{mg} / \mathrm{kgBB}$, dan $800 \mathrm{mg} / \mathrm{kgBB}$ terbukti mampu menghambat perlemakan hati.

Menurut Hetta et al. (2017) pemberian akar bayam dosis $400 \mathrm{mg} / \mathrm{kg}$ pemberian selama 28 hari dapat menurunkan kadar SGOT dan SGPT dengan nilai kadar 37,84U/L dan 43,17U/L. Kemudian pemberian bunga bayam dosis $400 \mathrm{mg} / \mathrm{kg}$ akar bayam pemberian selama 28 hari dapat menurunkan kadar SGOT dan SGPT dengan nilai kadar 38,33U/L dan 48,19U/L. Ekstrak etanol akar bayam lebih kuat dibandingkan bunga bayam baik pemeriksaan in-vitro atau in-vivo yang lebih berkore-lasi dengan kandungan sterol dibandingkan dengan kandungan flavonoid.

Menurut Pradana et al. (2017) pemberian ekstrak bayam merah dosis $200 \mathrm{mg} / \mathrm{kg}, \quad 400 \mathrm{mg} / \mathrm{kgBB}, \quad$ dan $800 \mathrm{mg} / \mathrm{kgBB}$ pemberian selama 67 hari dapat menurunkan kadar SGOT dan SGPT dengan nilai kadar SGPT 69,54U/L, 73,63U/L, dan 68,42U/L. Menurut Nahar et al., (2018) pemberian ekstrak bayam merah dosis $50 \mathrm{mg} / \mathrm{kg}, 100 \mathrm{mg} / \mathrm{kgBB}$, dan $200 \mathrm{mg} / \mathrm{kgBB}$ pemberian selama 14 hari dapat menurunkan kadar SGOT dan SGPT dengan nilai kadar 28U/L, 26U/L, 25U/L dan 22U/L, 20U/L, 18U/L. Sementara pemberian ekstrak bayam merah dari awal pada tikus ovariektomi selama 14 hari yang diinduksi ISO, kadar SGOT dan SGPT tetap dalam keadaan normal.

Menurut Singh et al. (2019) pemberian ekstrak ethanolik bayam merah dosis $200 \mathrm{mg} / \mathrm{kg}$, 400mg/kgBB pemberian selama 67 hari dapat menurunkan kadar SGOT dan SGPT dengan nilai kadar $65,24 \mathrm{U} / \mathrm{L}, \quad 58,32 \mathrm{U} / \mathrm{L}$, dan 76,82U/L, $56,32 \mathrm{U} / \mathrm{L}$. Sementara pemberian ekstrak air bayam merah dosis $200 \mathrm{mg} / \mathrm{kg}$, $400 \mathrm{mg} / \mathrm{kgBB}$ pemberian selama 67 hari dapat menurunkan kadar SGOT dan SGPT dengan nilai kadar 72,54U/L, 60,34U/L, dan 72,54U/L, 60,34U/L. Pemberian ekstrak bayam merah dengan dosis $200 \mathrm{mg} / \mathrm{kgBB}, \quad 400 \mathrm{mg} / \mathrm{kgBB}$, dan atorvastatin $10 \mathrm{mg}$ selama 22 hari dapat menyebabkan penurunan yang signifikan terhadap SGOT, SGPT, ALP dan CKMB (Singh et al., 2019).

Menurut Torales et al. (2019) pemberian ekstrak bayam merah dosis $5 \%$, dan 2,5\% pemberian selama 35 hari dapat menurunkan kadar SGOT dan SGPT dengan nilai kadar 88,28U/L, 106,1U/L, dan 28,95U/L, 34,40U/L. Selain itu pemberian ekstrak bayam merah dosis $5 \%$ yang diinduksi diet tinggi lemak dan 2,5\% yang diinduksi diet tinggi lemak pemberian selama 35 hari dapat menurunkan kadar SGOT dan SGPT dengan nilai kadar 139,2U/L, 142,7U/L dan 45,43U/L, 44,30U/L. Menurut Islam, 
(2019) pemberian ekstrak bayam merah diinduksi diabetic dan ekstrak bayam merah diinduksi non diabetic pemberian selama 14 hari dapat menurunkan kadar SGOT dan SGPT dengan nilai kadar 41,4U/L, 38,2U/L dan 42,2U/L, 40,7U/L.

Berdasarkan dari 8 jurnal terkait pemberian dosis dan lama waktunya bermacam-macam. Berdasarkan kurva penggunaaan dosis yang efektif mampu menurunkan kadar SGOT dan SGPT adalah dosis $200 \mathrm{mg} / \mathrm{kgBB}$ dan 400mg/kgBB dengan lama pemberian 7 29 hari.

\section{KESIMPULAN}

Berdasarkan hasil penelitian studi literatur dari 8 jurnal tersebut, maka dapat disimpulkan bahwa, diet tinggi lemak dapat menyebabkan hiperlipidemia dan NAFLD, ekstrak bayam merah (Amaranthus tricolor L.) mengandung senyawa flavanoid, kuersetin, tanin, saponin, alkaloid, fenolat, dan oksalat. Ekstrak bayam merah (Amaranthus tricolor L.) dapat menurunkan kadar SGOT dan SGPT pada tikus putih (Rattus norvegicus) yang diberi diet tinggi lemak. Dosis yang digunakan untuk menurunkan kadar SGOT dan SGPT yaitu $200 \mathrm{mg} / \mathrm{kg}$ dan $400 \mathrm{mg} / \mathrm{kgBB}$ dengan lama pemberian ekstrak yang efektif 7 sampai 29 hari.

\section{UCAPAN TERIMA KASIH}

Penelitian ini dapat dilaksanakan dengan baik, berkat bantuan dan dukungan dari berbagai pihak, untuk itu peneliti mengucapkan terima kasih kepada Universitas Malahayati, pembimbing, penguji, keluarga, rekan - rekan penelitian, serta teman - teman yang tidak bisa saya sebutkan satu persatu. Semoga skripsi ini bermanfaat bagi wawasan dan perkembangan ilmu pengetahuan.

\section{DAFTAR PUSTKA}

Adiwinata, R., Kristanto, A., Cristianty, F., Ricard, T., dan Edbert, D. (2015).
Tatalaksana Terkini Perlemakan Hati Non Alkoholil. Jurnal Kedokteran Katolik Indonesia Atma Jaya, 2 (1).

Aneja, S., Vats, M., Aggarwal, S., Sardana, S. (2013). Phytochemistry and hepatoprotective activity of aqueous extract of Amaranthus tricolor Linn. Roots. Journal of Ayurveda \& Integrative Medicine 4 (4).

Hettaa, M.H., Moawadb, A.S., Hamedc, M.A.A., dan Sabria, A.I. (2017). Invitro and In-vivo Hypolipidemic Activity of Spinach Roots and Flowers. 16 (4): 1509-1519.

Islam, MD., S. (2020). Antidiabetic and Antihypercholesterolemic Activities of Decoction of Amaranthus tricolor on Alloxan-induced Diabetic Rats. Journal of Science and Engineering, Department of Pharmacy, Southeast University, Dhaka, Bangladesh, 14 (1).

Nahar, K., Kabir, F., Islam, P., Rahman, M. Md., Mamun, Md., Mamun, A.AL., Faruk, Md., Subhan, N., Rahman, G.M.S., Reza, H.M., Alam, Md.A. (2018). Cardioprotective effect of Amaranthus tricolor extract in isoprenaline induced myocardial damage in ovariectomized rats. Department of Pharmaceutical Sciences, North South University, Bangladesh.

Nasution, A. Y., Adi, P., dan Santosa, P. A. (2016). Pengaruh Ekstrak Propolis terhadap Kadar Serum Glutamic Oxaloacetic Transaminase (SGOT) dan Serum Glutamic Pyruvic Transaminase (SGPT) pada Tikus Putih (Rattus norvegicus) Galur Wistar dengan Diet Tinggi Lemak. Majalah Kesehatan FKUB, 2(3), 120-126.

Nasution, A.D., Adi, P., Santosa, P, A. (2015). Pengaruh Ekstrak Propolis terhadap Kadar SGOT (Serum Glutamic Oxaloacetic Transaminase) dan SGPT (Serum Glutamic Pyruvic Transaminase) pada Tikus Putih (Rattus norvegicus) Galur Wistar dengan Diet Tinggi Lemak, Majalah Kesehatan 
FKUB, 2(3).

Pradana, D. A., Dwiratna, D. W. dan Widyarini, S. (2017). Aktivitas Ekstrak Etanolik Bayam Merah (Amaranthus tricolor L.) Terstandar sebagai Upaya Preventif Steatosis: Studi in Vivo, Jurnal Sains Farmasi \& Klinis, 3(2), 120.

Pradana, D. A., Anggriani, I.D., Setyaningrum, T.R. (2016). Potential of Red Spinach Leaves Ethanolic Extract (Amaranthus tricolor L.) as a Complementary Therapy For Hiperlipidemia: Study in Vivo of Histopathologic and Activity of Alanin Aminotransferase (ALT). Departement of Pharmacy, Universitas Islam Indonesia, Jurnal Sains Farmasi dan Klinis.

Prahastuti, S. et al. (2020). The Effect of Bee Pollen on SGOT, SGPT Levels and Liver Histopathological Images of Male Rats Wistar Induced by High Fat Diet, Journal of Medicine and Health, 2(5), 51-60.

Pramesti, R., dan Widyastuti, N. (2014). Pengaruh Pemberian Jus Daun Ubi Jalar (Ipomoea batatas L. Lam) Terhadap Kadar Kolesterol LDL Tikus Wistar Jantan (Rattus norvegicus) yang Diberi Pakan Tinggi Lemak, Journal of Nutrition College, 3(4), 706-714.

Singh, L., Kumar S., and Khan N.A. (2019). Exploring The Potential Effects Of
Amaranthus tricolor Leaves In Dyslipidemia And Dyslipidemia Induced Complications In Rats. International Journal of Pharmaceutical Sciences and Research, Vol. 10(8): 3937-3945

Sugiyono. (2016). Metode Penelitian Kualitatif, Kuantitatif dan $\mathrm{R} \& \mathrm{D}$. Bandung : Alfabeta

Sulistyaningrum, N. (2014). Isolasi dan Identifikasi Stuktur Karotenoid dan Ekstak Bayam Merah (Amaranthus tricolor L.), Jurnal Kefarmasian Indonesia, 75-81.

Supardi. (2018). Model Prediksi Kejadian Hiperlipedemia Peserta Akses di Kecamatan Metro Timur Kota Metro. Jurnal Wacana Kesehatan, 3(1).

Tirosh, O. (2014). Liver Metabolism and Fatty Liver Disease, Liver Metabolism and Fatty Liver Disease. Torales, L.I.E., Pozuelo,G.M., Barrio, R.G., González, I.N., Pallarés, F.J., Santaella, M., Alonso, J.G., Sevilla A., and Castón, M.J.P., 2019 Ameliorative Effect of Spinach on Non-Alcoholic Fatty Liver Disease Induced in Rats by a High-Fat Diet, International Journal of Molecular Sciences.

Word Health Organiszation (WHO). (2013). Departement of Management of Noncommunicable Diseases, Geneva, Switzerland. 